\title{
Monitoring Pergerakan Lindi Menggunakan Metode Geolistrik Time-Lapse di Sekitar Pemukiman Tempat Pembuangan Akhir Batu Layang Pontianak
}

Dzulfahmia, Okto Ivansyah ${ }^{\mathrm{b} *}$, Zulfian ${ }^{\mathrm{a}}$

\author{
aProdi Fisika, FMIPA Universitas Tanjungpura, FMIPA Universitas Tanjungpura \\ bPoliteknik Negeri Pontianak \\ *Email : oktoivansyah@yahoo.com
}

\begin{abstract}
Abstrak
Telah dilakukan penelitian untuk monitoring pergerakan lindi pada Tempat Pembuangan Akhir (TPA) Batu Layang. Sebaran lindi dimonitor menggunakan metode geolistrik resistivitas konfigurasi WennerSchlumberger dengan sampel sebanyak 2 lintasan. Pengambilan data kedua lintasan tersebut dilakukan secara time-lapse, yaitu menggunakan variasi waktu dalam pengambilan data. Variasi waktu tersebut dilakukan setiap satu pekan sekali selama tiga pekan. Berdasarkan analisis penampang resistivitas lindi mempunyai nilai resistivitas kurang dari $10 \Omega \mathrm{m}$. Pergerakan lindi dari pekan pertama hingga pekan ketiga pada lintasan 1 teridentifikasi mulai dari kedalaman 0,75-27,5 meter dari permukaan, sedangkan pada lintasan 2 termonitoring dari kedalaman 9 - 27,5 meter dari permukaan. Pada lintasan 1 pergerakan lindi menyebar hingga 116 meter dari awal lintasan, sedangkan pada lintasan 2 menyebar dari 25 - 112 meter dari awal lintasan. Sehingga pergerakan lindi dari TPA Batu Layang menyebar sejauh 334 meter ke arah Barat dari TPA Batu Layang.
\end{abstract}

Kata Kunci : Lindi, Geolistrik resistivitas, Time-lapse

\section{Pendahuluan}

Tempat Pembuangan Akhir (TPA) Batu Layang merupakan salah satu TPA terbesar yang berada di Kota Pontianak. TPA tersebut menerapkan sistem open dumping. Adapun penerapan sistem open dumping dapat menimbulkan pencemaran lingkungan di sekitar TPA seperti terbentuknya rembesan lindi yang dapat mencemari air permukaan, mencemari tanah, dan mencemari air bawah tanah yang berada di lapisan akuifer. Pencemaran pada lapisan akuifer dapat disebabkan oleh jumlah sampah di TPA sampah yang sangat besar ditambah dengan air hujan sehingga air lindi mudah terbentuk dan terserap ke dalam tanah hingga ke lapisan akuifer.

Geolistrik adalah salah satu metode geofisika yang dapat digunakan dalam survei identifikasi maupun eksplorasi bawah permukaan. Penerapan metode geolistrik telah banyak digunakan dalam hal survei identifikasi fluida bawah permukaan. Pemanfaatan metode ini telah dilakukan untuk identifikasi lindi dari TPA sampah di Bali [1] dan di Pontianak [2]. Kedua penelitian tersebut menggunakan konfigurasi yang sama yaitu WennerSchlumberger.

Metode time-lapse adalah suatu metode yang biasa digunakan dalam hal fotografi, yaitu mengambil suatu gambar atau foto dalam selang waktu tertentu. Metode time-lapse dapat diaplikasikan dalam metode geolistrik untuk memantau daerah rawan longsor di Kota Padang [3] dan juga diterapkan untuk memonitoring pergerakan fluida bawah permukaan (air tanah) di Kelurahan Tondo, Kota Palu [4].

Peneliti tertarik untuk melakukan penelitian dengan menggunakan gabungan antara dua metode yaitu metode geolistrik dan metode time-lapse karena untuk memonitor diperlukan pengamatan secara kontinyu. Objek dari penelitian yang akan dilakukan adalah fluida bawah permukaan yaitu lindi di sekitar pemukiman TPA sampah Batu Layang Pontianak. Penelitian ini diharapkan dapat memberikan informasi kepada warga yang tinggal di sekitar TPA dan warga Pontianak pada umumnya.

\section{Metodologi}

\subsection{Lokasi dan Waktu Penelitian}

Waktu penelitian dimulai pada bulan April hingga Mei 2018. Lokasi penelitian adalah di sekitar area TPA sampah Batu Layang, Kecamatan Pontianak Utara, Kota Pontianak, Kalimantan Barat. Ada 2 lintasan yang digunakan, lintasan 1 berada pada koordinat $0^{\circ} 1$ '28,36" LU dan 109¹9'16.92" BT - 0¹'28.85" LU dan $109^{\circ} 19^{\prime} 12.20^{\prime \prime}$ BT dan lintasan 2 berada pada koordinat $0^{\circ} 1{ }^{\prime} 28.85^{\prime \prime} \mathrm{LU}$ dan $109^{\circ} 19^{\prime} 12.20^{\prime \prime}$ BT - 0¹'29.02" LU dan 109¹9'7.90" BT seperti yang terlihat pada Gambar 1. 


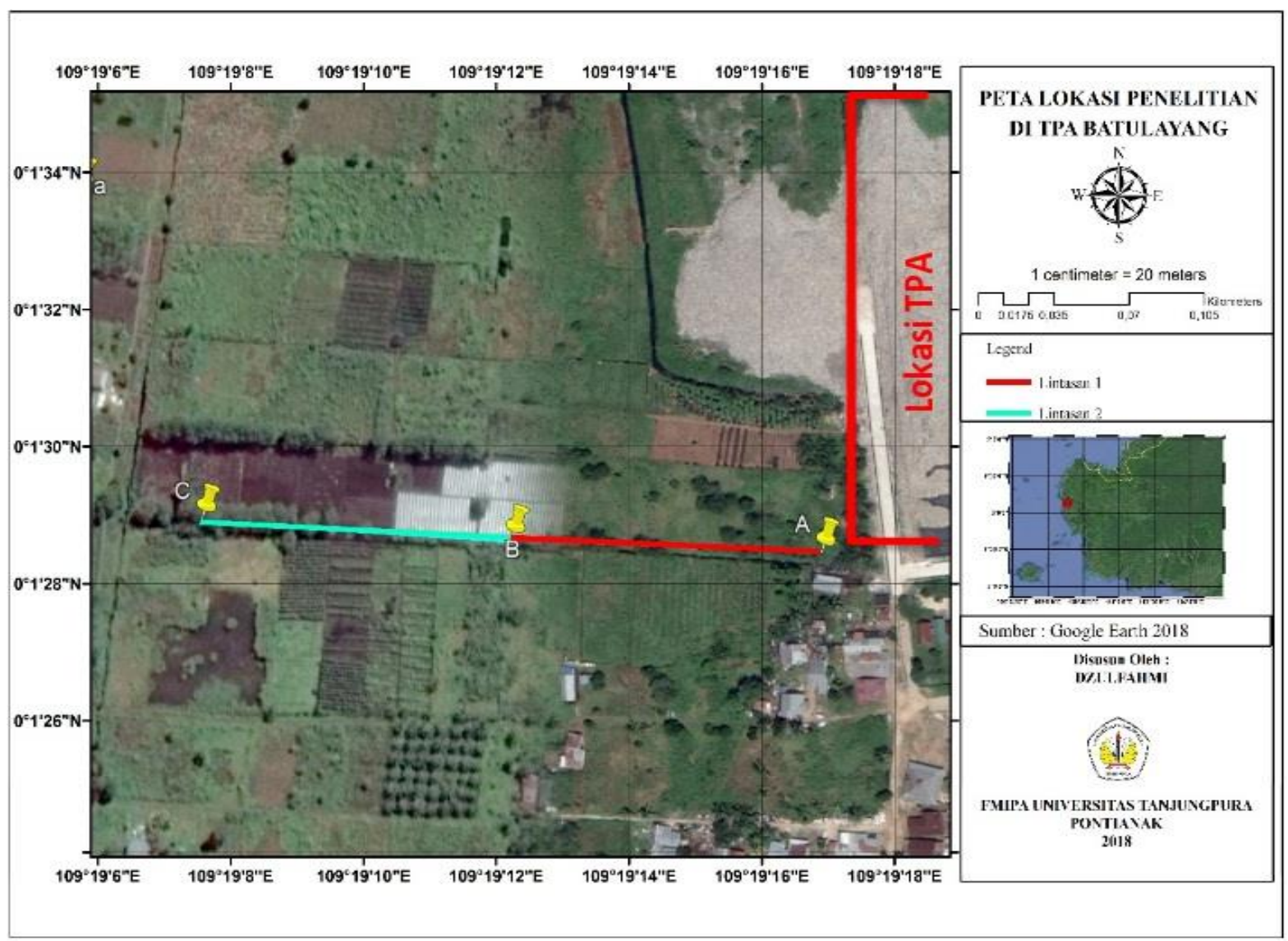

Gambar 1. Peta lokasi penelitian [5]

\subsection{Alat} adalah

Alat yang digunakan pada penelitian ini

1. Elektroda 48 buah

2. Kabel penghubung

3. Meteran

4. 1 set alat Resistivity meter

5. GPS

6. $A C C U$

\subsection{Tahapan Penelitian}

Konfigurasi yang digunakan adalah konfigurasi Wenner-Schlumberger. Metode geolistrik resistivitas dalam penelitian ini menerapkan konsep time-lapse, maka dari itu pengambilan data dilakukan setiap satu pekan sekali selama tiga pekan yang dilakukan secara kontinyu. Penerapan metode ini bertujuan untuk memonitor pergerakan lindi. Spasi antar elektroda sebesar 3 meter dengan menggunakan elektroda sebanyak 48 buah sehingga panjang satu lintasan adalah 144 meter, total panjang dari kedua lintasan adalah 288 meter. Seperti yang terlihat pada gambar 1, lintasan pertama berjarak sekitar 46 meter dari TPA, dan lintasan kedua dimulai dari titik akhir lintasan pertama.

\section{A. Proses Pengambilan Data}

Langkah - langkah pengambilan data resistivitas di lapangan melalui proses sebagai berikut :

1. Koordinat lintasan yang digunakan di tentukan menggunakan GPS

2. Panjang lintasan diukur menggunakan meteran

3. Elektroda sebanyak 48 buah dipasang di sepanjang lintasan dengan jarak antar elektroda sebesar 3 meter

4. Elektroda yang telah ditancapkan kemudian dihubungkan dengan alat resistivity meter yang telah dirangkai dan dihubungkan dengan accu sebagai sumber daya listrik

5. Arus listrik dari alat resistivity meter diinjeksikan melalui elektroda yang telah terhubung oleh kabel penghubung

6. Nilai arus dan beda potensial yang muncul pada alat resistivity meter akan terekam secara otomatis

7. Alat resistivity meter akan berhenti secara otomatis setelah didapatkan nilai arus dan beda potensial setiap datum

\section{B. Pengolahan Data}

Prosedur pengolahan data sebagai berikut : 
1. Memindahkan hasil pengukuran dari alat resistivity meter ke komputer

2. Hasil pengukuran tersebut langsung dapat diinversi menggunakan perangkat lunak Res2Dinv

Hasil yang diperoleh dari pengukuran di lapangan adalah nilai arus dan beda potensial. Dari pengukuran ini resistivitas yang sebenarnya dari bawah permukaan dapat diperkirakan. Resistivitas tanah berkaitan dengan berbagai parameter geologi seperti mineral dan konten cairan, porositas, derajat patahan, persentase dari patahan diisi dengan air tanah dan derajat dari saturasi air di batuan [6].

\section{Hasil dan Pembahasan}

\subsection{Sebaran Lindi}

Berdasarkan hasil interpretasi menggunakan parameter resitivitas dan studistudi terkait, maka interpretasi dalam inversi data dapat dilakukan dengan mengamati penampang 2 dimensi untuk menentukan adanya sebaran lindi yang ada di bawah permukaan. Berdasarkan penelitian yang telah dilakukan sebelumnya menurut Apriasti (2016) lindi merupakan cairan konduktif yang memiliki nilai resistivitas kecil yaitu kurang dari $10 \Omega \mathrm{m}$. Pada penelitian ini juga diperoleh nilai resistivitas rendah yaitu kurang dari $10 \Omega \mathrm{m}$ sehingga dapat diinterpretasikan sebagai rembesan lindi.

\subsubsection{Lintasan 1 dan 2 Pekan pertama}

Masing-masing lintasan tersebut mempunyai panjang 144 meter dengan menggunakan spasi antar elektroda 3 meter. Kedalaman maksimal yang terukur adalah 27,5 meter. Pada lintasan 1 rentang nilai resitivitas yaitu $0-25,7 \Omega \mathrm{m}$ dan pada lintasan 2 , rentang nilai resistivitas yaitu $0-31,4 \Omega \mathrm{m}$. Berdasarkan Peta Geologi Lembar Singkawang, Kalimantan [7] formasi batuan di dearah TPA Batu Layang terdiri dari lumpur, pasir, batu kerikil, batu gamping, dan sisa tumbuhan. Dari tabel nilai resistivitas Telford, dkk (1990) nilai resistivitas pasir $1-1000 \Omega \mathrm{m}$, lempung $1-100 \Omega \mathrm{m}$ dan air dalam aluvial sebesar $10-30 \Omega \mathrm{m}$, pasir dan kerikil mengandung air tawar $20-500 \Omega$, dan batu gamping memilki nilai resistivitas lebih dari $240 \Omega \mathrm{m}$.

Pada gambar 2 (a) terlihat beberapa titik dengan nilai resistivitas rendah yaitu kurang dari $10 \Omega$ m yang diinterpretasikan sebagai lindi. Pada lintasan 1 terlihat bahwa lindi tersebar di beberapa tempat dan kedalaman tertentu. Dimulai pada jarak 7 - 19 meter dengan kedalaman 0,75 - 6 meter dari permukaan. Dugaan lindi berikutnya berada pada jarak 43 87 meter dengan kedalaman 1 - 6 meter dari permukaan. Dugaan akumulasi lindi yang paling banyak terdapat pada jarak 24 - 117 meter dengan kedalaman 9 meter hingga kedalaman maksimum yaitu 27,5 meter. Pada lintasan 2, gambar 2 (b) lindi mulai terlihat pada jarak 20 114 meter dengan kedalaman 10 meter hingga kedalaman maksimal yaitu 27,5 meter. Nilai resistivitas $10,4-31,4 \Omega \mathrm{m}$ pada lintasan 1 dan lintasan 2 pada pekan pertama merupakan nilai resitivitas lempung beserta pasir dan kerikil yang bercampur air tanah.

Banyaknya lindi yang tersebar di kedalaman yang masih dekat dengan permukaan pada lintasan 1 disebabkan karena jarak lintasan 1 tidak jauh dari lokasi TPA yaitu sekitar 46 meter. Penyebab tidak terlihatnya lindi pada kedalaman yang masih dekat dengan permukaan pada lintasan 2 adalah jaraknya yang cukup jauh dari TPA yaitu sekitar 190 meter.

\subsubsection{Lintasan 1 dan 2 Pekan Kedua}

Pada minggu ke 2, lokasi penelitian, jarak antar elektroda dan panjang lintasan 1 tidak berubah masih seperti pada minggu pertama. Kedalaman maksimal yang terukur berdasarkan hasil inversi adalah 27,5 meter dengan rentang nilai resitivitasnya sebesar $0-40,8 \Omega \mathrm{m}$ pada lintasan 1 dan pada lintasan 2 rentang nilai resistivitasnya sebesar $2,35-32,8 \Omega \mathrm{m}$.

Pada lintasan 1, gambar 3(a) terlihat bahwa lindi masih tetap tersebar di beberapa jarak dan kedalaman tertentu. Dimulai pada jarak $6-10$ meter dengan kedalaman 0,75 - 2 meter dari permukaan. Dugaan lindi berikutnya berada pada jarak $34-40$ meter, 60 - 67 meter dengan kedalaman 0,75 - 2 meter dari permukaan. Pada jarak antara 77 - 80 meter lindi tersebar dari kedalaman minimum 0,75 meter hingga kedalaman maksimum 27,5 meter. Dugaan akumulasi lindi yang paling banyak terdapat pada jarak 24-124 meter dengan kedalaman 7 meter hingga kedalaman maksimum yaitu 27,5 meter. Pada lintasan 2, gambar 3 (b) lindi mulai terlihat pada jarak 27 - 114 meter dengan kedalaman 8 meter hingga kedalaman maksimal yaitu 27,5 meter. Pada pekan kedua ini nilai resistivitas 10,4 - 40,8 $\Omega \mathrm{m}$ merupakan nilai resistivitas campuran air tanah, pasir, kerikil, dan lempung.

Faktor jarak dari TPA ke lintasan 1 dan ke lintasan 2 sangat memengaruhi distribusi sebaran lindi. Pada lintasan 1 mempunyai jarak yang lebih dekat dengan TPA dibandingkan dengan lintasan 2. Oleh karena itu sebaran lindi pada lintasan 1 hampir dapat terlihat pada setiap jarak dan kedalaman, sedangkan pada lintasan 2 sebaran lindi hanya terakumulasi pada kedalaman tertentu. Air yang terkandung pada sampah berpengaruh dalam pembentukan lindi 
selain itu faktor curah hujan di lokasi penelitan juga berpengaruh terhadap pembentukan dan distribusi sebaran lindi.

\subsubsection{Lintasan 1 dan 2 Pekan Ketiga}

Pada pekan ketiga lokasi penelitian masih pada tempat yang sama seperti pada pekan pertama dan pekan kedua. Panjang lintasan 1 maupun lintasan 2 serta jarak antar elektroda juga tetap sama. Kedalaman minimalnya adalah sebesar 0,75 meter dan kedalaman maksimum yang terukur berdasarkan hasil inversi adalah 27,5 meter dan rentang nilai resitivitas pada pekan ketiga relatif lebih kecil daripada pekan pertama dan pekan kedua yaitu sebesar $0-14,1$ $\Omega$ m pada lintasan 1 dan pada lintasan 2 , rentang nilai resistivitasnya sama dengan pekan kedua yaitu sebesar $0-32,8 \Omega \mathrm{m}$.

Pada pekan ketiga di lintasan 1, gambar 4 (a) dugaan lindi masih tetap tersebar di beberapa jarak dan kedalaman tertentu seperti pada pekan pertama dan pekan kedua. Keberadaan lindi bermula pada jarak 12 - 17 meter dengan kedalaman 0,75 - 3 meter dari permukaan. Dugaan lindi berikutnya berada pada jarak 37 40 meter seperti halnya pada pekan kedua namun kedalamannya berada pada $1-4$ meter dari permukaan. Kemudian dugaan lindi selanjutnya berada pada jarak 58 - 80 meter dengan kedalaman 0,75 - 4 meter. Dugaan akumulasi lindi yang paling banyak pada pekan ketiga hampir sama dengan pekan pertama dan pekan kedua yaitu terdapat pada jarak $24-117$ meter dengan kedalaman 10 meter hingga kedalaman maksimum yaitu 27,5 meter. Hampir sama halnya pada pekan pertama dan pekan kedua pada lintasan 2, gambar 4 (b) lindi hanya terlihat pada jarak 27 - 114 meter dengan kedalaman 9 meter hingga kedalaman maksimum yaitu 27,5 meter. Hampir sama dengan pekan pertama nilai resistivitas 10,4 $32,8 \Omega \mathrm{m}$ merupakan nilai resistivitas untuk pasir, kerikil, dan lempung yang mengandung air tanah.

\subsection{Monitoring Pergerakan Lindi}

Metode pengukuran geolistrik time-lapse bertujuan untuk monitoring pergerakan lindi di bawah permukaan dalam waktu yang pendek. Kondisi lokasi penelitian adalah hamparan tanah gambut yang luas yang berada 46 meter dari lokasi TPA sampah dan juga terdapat beberapa pemukiman warga. Pengukuran geolistrik timelapse ini menggunakan konfigurasi WennerSchlumberger dengan spasi 3 meter antar elektroda yang dilakukan selama tiga pekan dan pengambilan data dilakukan setiap satu pekan sekali.

Cairan lindi ini terbentuk oleh kandungan air yang terdapat pada sampah. Adanya hujan yang terjadi di TPA sampah membuat lindi semakin mudah terbentuk dan sebaran lindi semakin luas. Oleh karena itu banyak sumur warga sekitar TPA sampah yang tercemar oleh cairan lindi, baik dari bawah permukaan maupun dari atas permukaan yang biasanya terjadi ketika hujan. Pada Gambar 2 dipekan pertama dapat diamati adanya sebaran lindi yang berada pada area-area tertentu, dimulai dari awal lintasan hingga ujung lintasan dan berada di kedalaman 0,75 hingga kedalaman maksimal 27,5 meter. Di kedalaman 0,75 - 6 meter dan pada jarak 7 - 19 meter, $34-36$ meter, $43-44$ meter, 51 - 55 meter, 60 - 64 meter, 67 - 70 meter dan $83-84$ meter terlihat sebaran lindi tidak terlalu banyak. Mulai pada kedalaman 7 - 27,5 meter dan pada jarak 24 - 116 meter terlihat lindi menumpuk pada lapisan tersebut.

Pada pekan kedua terlihat perubahan posisi lindi dari pekan pertama di kedalaman dekat dengan permukaan maupun yang jauh dari permukaan. Hal ini disebabkan oleh curah hujan yang terjadi selama selang waktu antara pengambilan data pekan pertama dan pekan kedua. Sebaran lindi dipekan kedua pada kedalaman 0,75 - 7 meter masih tersebar pada beberapa tempat, diantaranya pada jarak $6-17$ meter, 33 - 40 meter, 52 - 53 meter, $59-69$ meter, dan 73 - 75 meter dan 89 - 92 meter. Akumulasi lindi paling banyak juga berubah dari pekan pertama, pada jarak 78 - 83 meter terdapat lindi dari kedalaman $0,75-27,5$ meter yang kemudian bercampur dengan lindi yang berada di kedalaman 11 - 27,5 meter yang dimulai dari jarak 24 - 83 meter. Ada juga sebaran lindi yang cukup banyak di kedalamanan 10 -15 meter pada jarak 96-116 meter. Hujan terjadi sebanyak 3 kali di lokasi penelitian selama selang waktu dari pekan pertama hingga pekan kedua.

Pekan ketiga keberadaan lindi agak jauh berbeda seperti yang ada pada pekan pertama dan pekan kedua. Hanya sedikit sebaran lindi yang ada di kedalaman 0,75 - 4 meter. Sebaran lindi tersebut hanya berada pada jarak $11-17$ meter, 37 - 40 meter, 53 - 54 meter, $59-63$ meter, dan 65 - 80 meter. Sedangkan pada jarak $24-116$ meter lindi terakumulasi di kedalaman 10 - 27,5 meter. kondisi tanah sangat kering hal ini di karenakan intensitas curah hujan di lokasi penelitan cukup rendah pada selang waktu dari pekan kedua hingga pekan ketiga. Terlihat dari waktu ke waktu pola sebaran lindi cukup mengalami perubahan yang signifikan. 


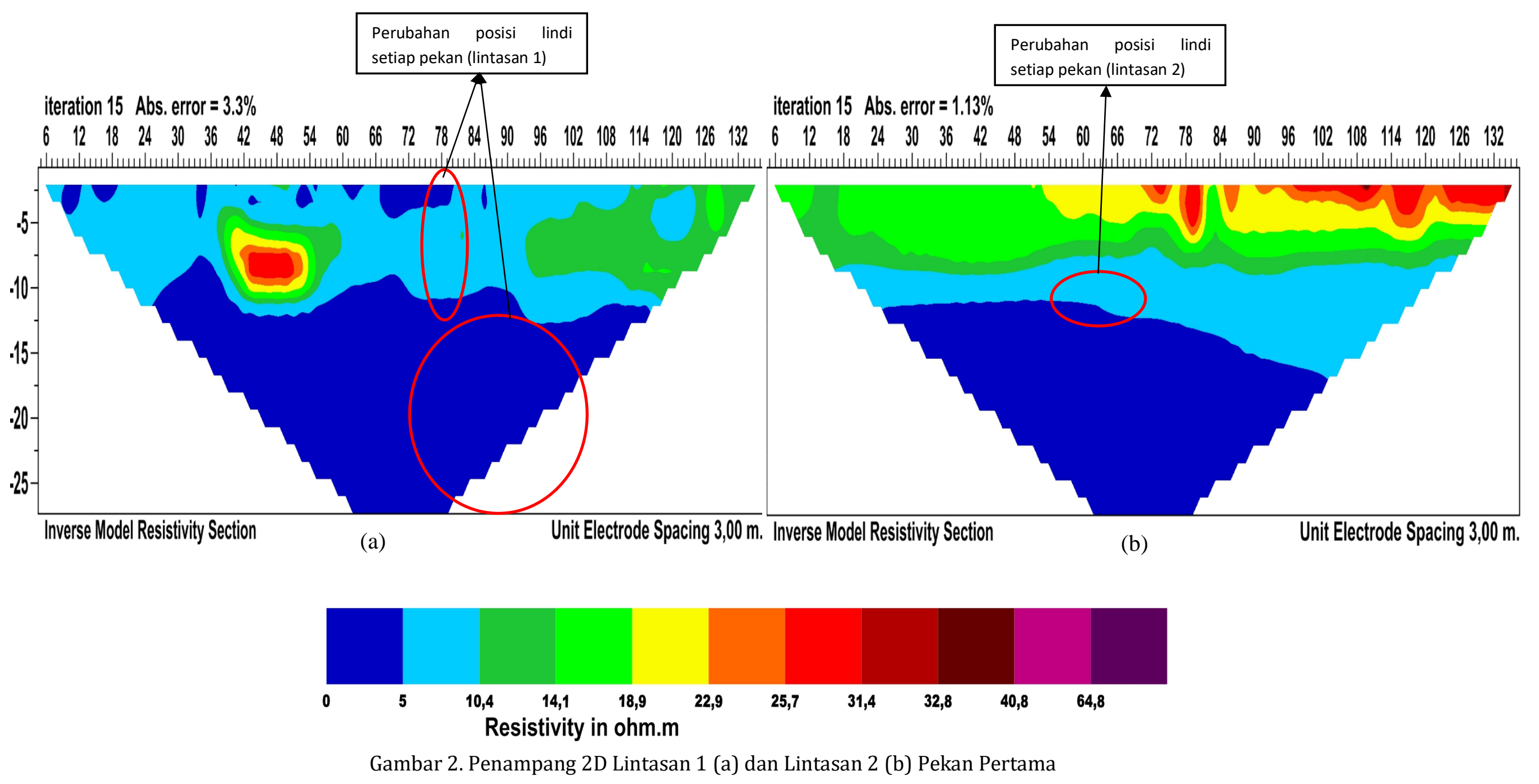




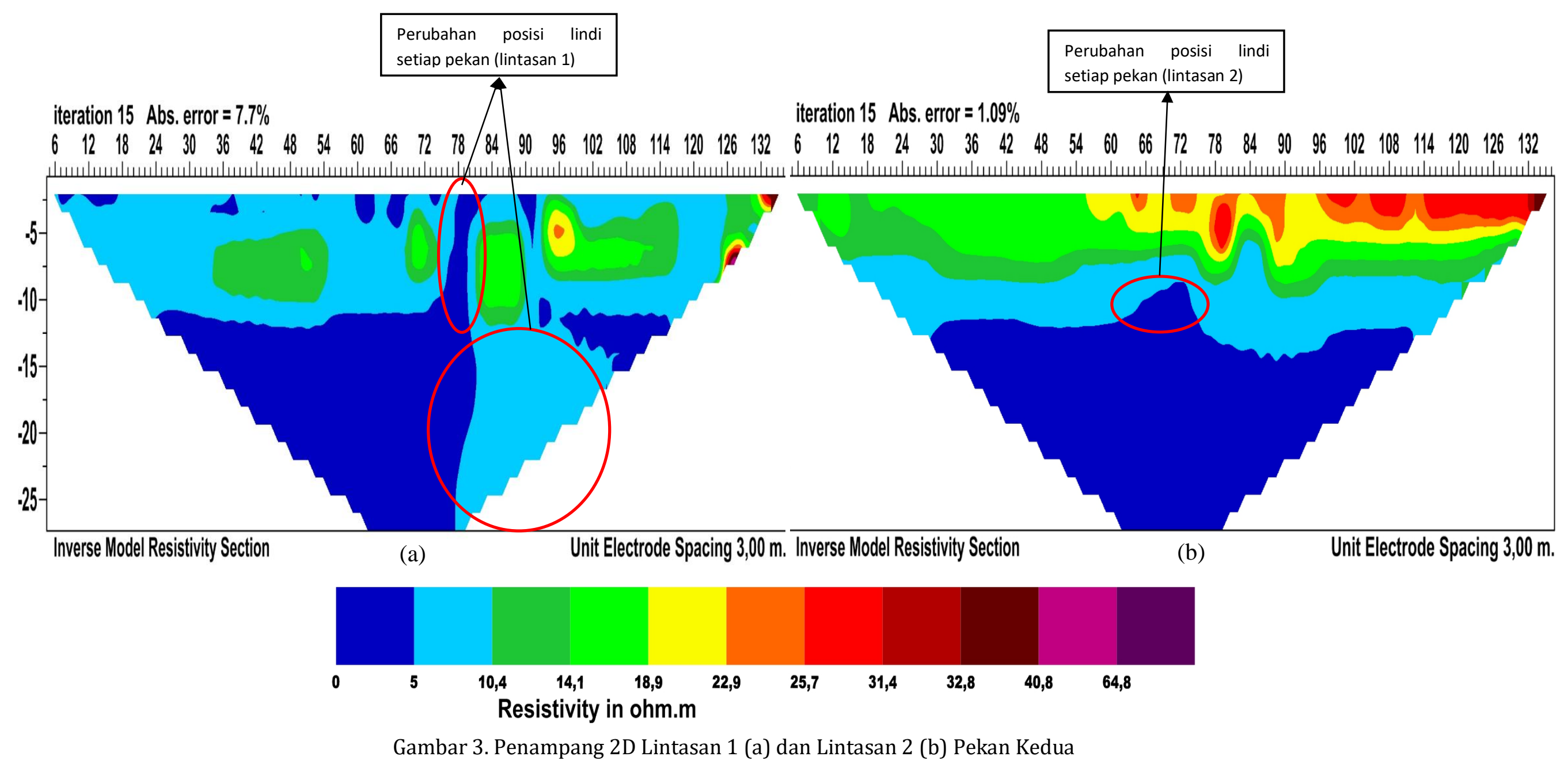

Gambar 3. Penampang 2D Lintasan 1 (a) dan Lintasan 2 (b) Pekan Kedua 


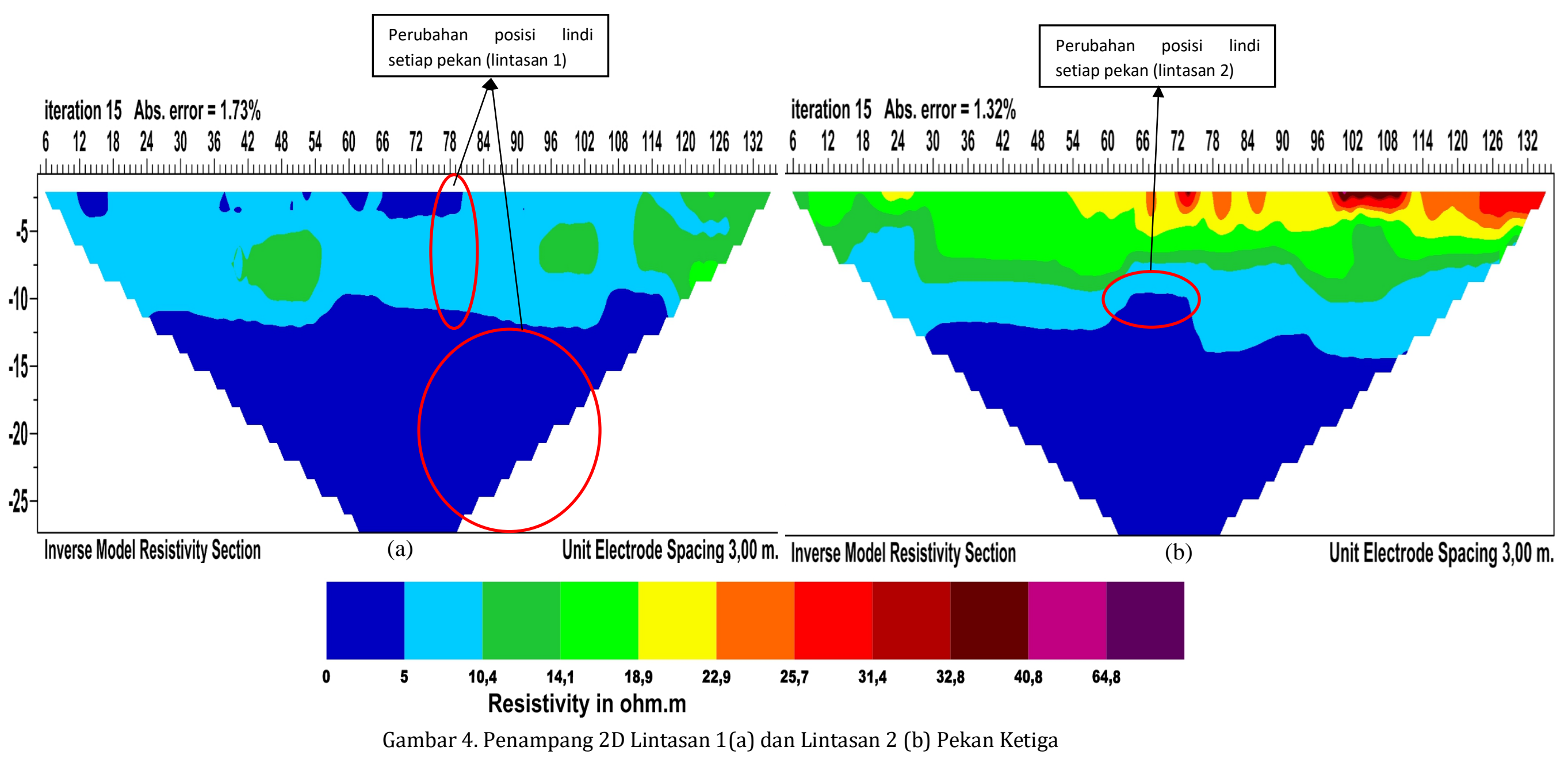


Hal ini megindikasikan volume lindi pada sistem lapisan tersebut tidak konstan, dikarenakan sifat lindi yang dinamis, bergerak menuju ruang lapisan berpori yang mampu menampung atau meluluskan fluida.

Hasil monitoring pergerakan lindi pada lintasan 2 tidak menunjukkan perubahan yang signifikan, hal ini dikarenakan jarak lintasan 2 dengan lokasi TPA sampah sekitar 190 meter. Oleh karena itu dari waktu ke waktu pada pekan pertama hingga pekan ketiga tidak terlihat adanya sebaran lindi yang berada di kedalaman yang dekat dengan permukaan, akan tetapi hanya terlihat akumulasi lindi yang berada di kedalaman tertentu. Pada pekan pertama akumulasi lindi mulai terbentuk di kedalaman 11 - 27,5 meter dan pada jarak 25 - 103 meter. Pada pekan kedua posisi lindi sedikit berubah dari pekan pertama yang seperti yang terlihat pada gambar 3, di pekan kedua akumulasi lindi terjadi mulai dari kedalaman 9 - 27,5 meter dan pada jarak 29 - 112 meter. Pekan ketiga kondisi tumpukan lindi tidak jauh berbeda dari pekan kedua, sebaran lindi hanya terakumulasi di kedalaman 10 - 27,5 meter dan pada jarak 29 112 meter dan tetap terlihat sebaran lindi berada di dekat permukaan. Hasil monitoring pergerakan lindi pada lintasan 1 dan lintasan 2 menunjukkan adanya rembesan lindi yang menyebar secara vertikal dan horizontal. Sebaran lindi secara dominan ke arah horizontal daripada vertikal hal ini disebabkan oleh lindi yang menyebar mengikuti pergerakan air tanah. Curah hujan yang terjadi di TPA Batu Layang berpengaruh dalam pembentukan lindi. Semakin sering terjadi hujan pada TPA Batu Layang akan semakin banyak lindi yang terbentuk, begitu pula sebaliknya.

\section{Kesimpulan}

Berdasarkan tujuan dan hasil penelitian yang telah dilakukan maka dapat ditarik suatu kesimpulan yaitu lindi tersebar di beberapa tempat dan kedalaman tertentu pada lintasan 1 dan lintasan 2, mulai dari kedalaman 0,75 - 27,5 meter dari permukaan dan dari jarak $6-124$ meter dengan nilai resistivitas rendah dibawah $10 \Omega \mathrm{m}$. Akumulasi lindi juga ditemukan pada lintasan 2 pada kedalaman $9-27,5$ meter. Hasil monitoring pergerakan lindi menunjukkan lindi bergerak baik secara vertikal maupun horizontal. Terlihat dari waktu ke waktu pola pergerakan lindi bergerak ke arah ruang lapisan berpori yang mampu menampung atau meluluskan.

\section{Saran}

Adapun saran untuk penelitian selanjutnya yaitu apabila menerapkan metode time-lapse untuk memonitoring pergerakan fluida bawah permukaan sebaiknya menggunakan periode waktu tertentu.

\section{Daftar Pustaka}

[1] Putra, I. K., 2012, Identifikasi Arah Rembesan Dan Letak Akumulasi Lindi Dengan Metode Geolistrik Resistivitas Konfigurasi Wenner - Schlumberger Di Tpa Temesi Kabupaten Gianyar, Universitas Udayana (skripsi), Denpasar

[2] Apriasti, R. E., 2016., Pola Sebaran Air Lindi Di TPA Batu Layang Dengan Metode Geolistrik Wenner-Schlumberger, Universitas Tanjungpura (skripsi), Pontianak

[3] Mahrizal, 2015, Pengembangan Teknologi Monitoring Geolistrik Time-Lapse Untuk Memantau Daerah Rawan Longsor Di Kota Padang Dengan Menggunakan Metoda Geolistrik Konfigurasi Wenner, Semirata (pp. 169-182), Universitas Tanjungpura, Pontianak

[4] Abdullah, I. A., 2017, Uji Penerepan Metode Geolistrik Time-Lapse Untuk Memonitoring Pergerakan Fluida Bawah Permukaan (Air Tanah) Di Lokasi Sumur Produksi Air Tanah Warga Kelurahan Tondo Kota Palu, Universitas Tadulako, Palu, 16:106-116

[5] Google Earth, Batu layang, Pontianak Utara Http://www.earthgoogle.com, (accessed 28 Mei 2017)

[6] Setiadi, M. Apriansyah dan Sampurno, J., 2016, Indentifikasi Sebaran Batuan Beku di Bukit Koci Desa Sempalai Kabupaten Sambas Kalimantan Barat dengan Menggunakan Metode Geolistrik, Positron, VI:p. 53 - 59, Universitas Tanjungpura, Pontianak

[7] Suwarna, N. dan Langpord, R., 1993, Peta Geologi Lembar Singkawang, Kalimantan, Pusat Penelitian dan Pengembangan Geologi, Bandung, 